\title{
Prediction of Biomass in Dry Tropical Forests: an Approach on the Importance of Total Height in the Development of Local and Pan-Tropical Models
}

Robson Borges de Lima ( $\square$ rblflorestal@yahoo.com.br )

Universidade do Estado do Amapá https://orcid.org/0000-0001-5915-4045

Cinthia Pereira de Oliveira

Universidade do Estado do Amapá

Rinaldo Luiz Caraciolo Ferreira

Universidade Federal Rural de Pernambuco

José Antônio Aleixo da Silva

Universidade Federal Rural de Pernambuco

Emanuel Araújo Silva

Universidade Federal Rural de Pernambuco

Francisco Tarcísio Alves Júnior

Univesidade do Estado do Amapá

Research

Keywords: Caatinga domain, Forest management, Allometry, Statistical models

Posted Date: August 7th, 2020

DOl: https://doi.org/10.21203/rs.3.rs-52272/v1

License: (9) (i) This work is licensed under a Creative Commons Attribution 4.0 International License.

Read Full License 
1 Prediction of biomass in dry tropical forests: an approach on the importance of total

2 height in the development of local and pan-tropical models

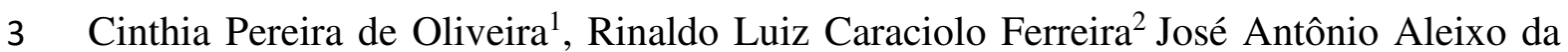

4 Silva $^{2}$ Robson Borges de Lima ${ }^{1 *}$, Emanuel Araújo Silva ${ }^{2}$, Francisco Tarcísio Alves

5 Júnior

6

$7 \quad *$ Corresponding author: Robson Borges de Lima - rbl_florestal@yahoo.com.br

8

$9 \quad{ }^{1}$ Laboratório de Manejo Florestal, Universidade do Estado do Amapá, Rua Presidente 10 Vargas, no 450, Centro, Macapá, Amapá, CEP 68901-262, Brasil

$12{ }^{2}$ Laboratório de Manejo de Florestas Naturais "José Serafim Feitosa Ferraz", 13 Departamento de Ciência Florestal, Universidade Federal Rural de Pernambuco, Rua 14 Dom Manuel de Medeiros, s/n - Dois Irmãos, Recife, Pernambuco, CEP 52171-900, 15 Brasil

Email

address

cinthia.florestal@gmail.com;

rinaldo.ferreira@ufrpe.b;

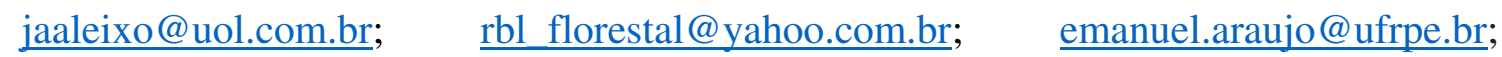

tarcisioalvesjr@yahoo.com.br 
Abstract

Background: Dry tropical forests in arid lands cover large areas in Brazil, but few studies report the total biomass stock showing the importance of height measurements, in addition to applying and comparing local and pan-tropical models of biomass prediction for the domain of trees and shrubs found in that environment. Here, we use a biomass data set of 500 trees and shrubs, covering 15 species harvested in a management plan in the state of Pernambuco, in Brazil. We seek to develop local models and compare them with the equations traditionally applied to dry forests - showing the importance of tree height measurements. Due to the non-linear relationships with the independent variables of the tree, we used a nonlinear least squares modeling technique when adjusting models, we adopted the cross-validation procedure. The selection of the models was based on the likelihood measures (AIC), total explained variation (R2) and forecast error (RSE, RMSE and Bias).

Results: In summary, our above-ground biomass data set is best represented by the Schumacher-Hall equation: $\exp [3.5336+1.9126 \times \log (\mathrm{D})+1.2438 \times \log (\mathrm{Ht})]$, which shows that height measurements are essential to estimate accurately biomass. The biggest prediction errors observed when testing pan-tropical models in our data demonstrated the importance of developing new local models and indicated that careful considerations should be made if generic "pantropical" models without height measurements are planned for application in dry forests in Brazil.

Conclusions: Thus, local equations can be used for carbon accounting in REDD + and sustainable incentive projects that initiate the development of dry forests and assess ecosystem services. 


\section{Background}

Dry tropical forests are a large reservoir of above-ground living biomass which play a key role in the global carbon cycle and are widely recognized as one of the main ecosystems that serve as a barrier to desertification (Salinas-Melgoza et al. 2018; Abich et al. 2018; Guha et al. 2019). Current efforts to quantify the global above-ground biomass and carbon stocks in these forests comprise dynamics and productivity (e.g., Avitabile et al. 2016; Wagner et al. 2016; Althoff et al. 2018), assess the conservation potential to mitigate climate change (e.g., Salis et al. 2006; Bastin et al. 2017) and examine the ecosystem function relationships of biodiversity (Chave et al. 2005a, 2014; Hiltner et al. 2018). All of these cases almost exclusively depend on robust estimates of aboveground carbon and biomass (AGB) storage. 
and Raghubanshi 2015), especially when compared with models that include tree height and/or basic wood density (Ali and Mattsson 2018) and are parameterized at local, regional or continental scales (Chave et al. 2014; Abich et al. 2018).

Thus, tree height is an important component of this allometric relationship as tree biomass is partly a function of tree volume, which is a function of tree height, trunk basal area and trunk taper (Chave et al. 2005; Sullivan et al. 2018). Although obtaining tree height in forest inventories is not an easy task (see Larjavaara and Muller-Landau 2013 for discussions), the incorporation of a height parameter is known to markedly improve the estimates of individual tree biomass scales (e.g., Sampaio and Silva 2005; Sampaio et al. 2010; Lima et al. 2017), and this has a substantial effect on pan-tropical scales as well (Feldpausch et al. 2012; Sullivan et al. 2018). As a result, in practice this can lead to incorporating tree height in REDD + carbon monitoring (Pelletier et al. 2017; Sullivan et al. 2018).

Several pan-tropical models were therefore developed to estimate biomass in dry tropical forests using models which only relate biomass to diameter (Návar 2015); basic wood diameter and density (Chave et al. 2005 - Type II.1 and Type II.3); diameter, height and basic wood density (Chave et al. 2005 - Type I.1 and Type I.5). However, these relationships can be expected to vary at various environmental and spatial scales (Ubuy et al. 2018), suggesting that even these developed pan-tropical or local models lack the sophistication required for many applications (Rutishauser et al. 2013).

In addition, it would be very useful to generally understand how tree height affects the reliability of local scale models in Brazilian dry tropical forests. In particular, ecologists and professionals with the aim of generating better accuracy of forest biomass estimates would benefit from knowledge that locally derived models consistently 
outperform existing regional and pan-tropical models, especially when the importance is verified in measuring tree height.

In this paper, we address these challenges by assembling a data set where 507 trees were sampled for biomass and total height measurement and examined to quantify how well the locally derived models predict the tree's biomass. A cross-validation approach was performed to enable testing the performance of different allometric models with and without height on data which are independent of those used for model fitting. The specific objectives were: (1) to examine how models with and without height derived from the site affect forecasting errors; and (2) to test different pan-tropical models with and without height to local data to verify the improvement in biomass prediction when a local model is not available for areas with and without change in its structure.

\section{Results}

Among the local equations, those obtained by the Schumacher-Hall and Chave et al. (2005) logarithmic models - Model I (5 and 6), showed better performance. Both equations produced similar values for RMSE, RSE, Bias and CV, but the best forecasts indicate a slight superiority of the Schumacher-Hall model, explaining more than $90 \%$ of the total variance and lower AIC value (Table 4). We noticed that the parameter related to basic density in the Chave et al. (2005) - Model I equation does not necessarily indicate statistical significance in biomass forecasts. In addition, with the exception of the Koperzky-Gehrhardt and Chave et al. (2005) equations - Model II, the other adjusted models presented significant parameters $(\mathrm{p}<0.05)$ with valid confidence intervals $(\mathrm{P}>$ 0.05). 
Table 4 Estimates of parameters and indexes of adequacy of allometric models for forecasting biomass in tropical dry forest, Northeast Brazil.

\begin{tabular}{cccccccccccc}
\hline $\begin{array}{c}\text { Local } \\
\text { models }\end{array}$ & $\beta_{0}$ & $\beta_{1}$ & $\beta_{2}$ & $\beta_{3}$ & $\beta_{4}$ & AIC & RSE & $R^{2}$ aj & RMSE & Bias & $\begin{array}{c}\text { CV } \\
(\%)\end{array}$ \\
\hline 1 & $-2.5851^{*}$ & $2.3599^{*}$ & - & - & - & 702.52 & 0.4819 & 0.8715 & 19.9242 & 0.2718 & 3.77 \\
2 & $-0.5999^{\text {ns }}$ & $0.6376^{\text {ns }}$ & - & - & - & 765.89 & 0.513 & 0.8543 & 65.0296 & 0.323 & 4.01 \\
3 & $-2.1445^{*}$ & $1.8207^{*}$ & $0.1499^{*}$ & - & - & 697.72 & 0.4791 & 0.8729 & 13.5859 & 0.2705 & 3.74 \\
4 & $-3.3722^{*}$ & $1.0053^{*}$ & - & - & - & 577.34 & 0.4259 & 0.8996 & 18.2462 & 0.2034 & 3.33 \\
$\mathbf{5}$ & $\mathbf{- 3 . 5 3 3 6 *}^{*} \mathbf{1 . 9 1 2 6}^{*}$ & $\mathbf{1 . 2 4 3 8}^{*}$ & - & - & $\mathbf{5 7 3 . 7 7}$ & $\mathbf{0 . 4 2 4 0}$ & $\mathbf{0 . 9 0 0 5}$ & $\mathbf{1 8 . 2 8 5}$ & $\mathbf{0 . 2 0 1 8}$ & $\mathbf{3 . 3 1}$ \\
6 & $-3.5466^{*}$ & $1.9180^{*}$ & $1.2399^{*}$ & $-0.0406^{\text {ns }}$ & - & 575.49 & 0.4243 & 0.9003 & 17.658 & 0.2010 & 3.32 \\
7 & $-3.1093^{*}$ & $3.5856^{*}$ & $-0.8313^{\text {ns }}$ & 0.1681 & $0.0083^{\text {ns }}$ & 697.59 & 0.4777 & 0.8737 & 16.532 & 0.2670 & 3.73 \\
8 & $-2.8154^{*}$ & $0.9325^{*}$ & - & - & - & 728.41 & 0.4943 & 0.8647 & 32.304 & 0.2762 & 3.86 \\
\hline
\end{tabular}

123 Note: Values in italics are not significant $(\mathrm{p} \geq 0.05)$ and the best model is in bold. *

124 significant at 0.05 .

The Schumacher-Hall equation selected for biomass prediction in local dry forest

126 predicts that the logarithmic transformation of diameter and height for a given tree weight

127 decreases the bias in the estimate. These results support the decision to use regression

128 methods to build models and estimate their parameters, therefore suggesting that it is

129 more parsimonious to maintain an allometric double entry model, in this case the

130 Schumacher-Hall model obtained for the area (Fig. 3).

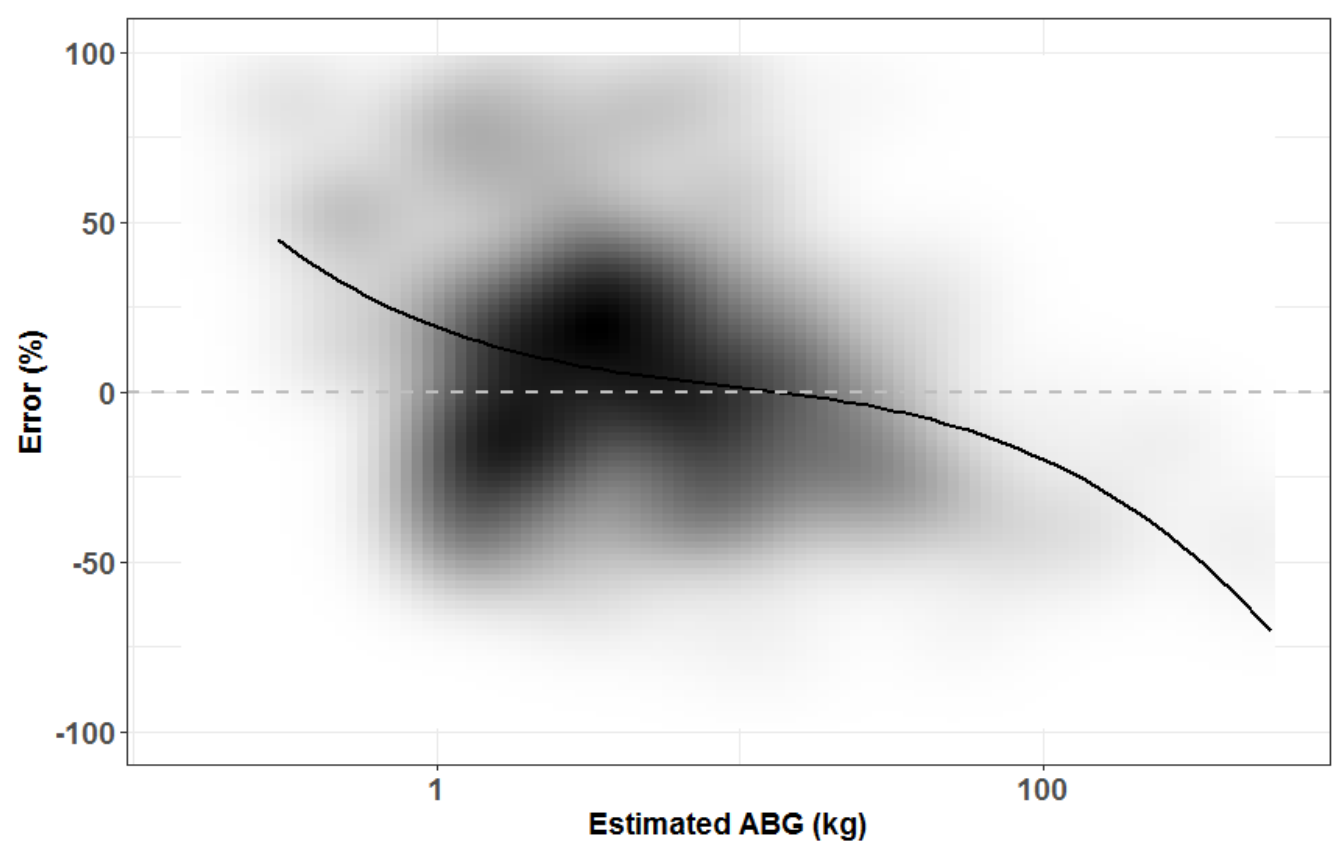


Fig. 3 Dispersion of percentage residues for the Schumacher-Hall equation developed to predict biomass in dry tropical forest, northeastern Brazil. expected values of biomass with the presence of few outliers in the lowest values.

However, it should be considered that the outliers suggest a curvature possibly caused by model errors rather than the data selected for the fit (trees which are unusually tall or short for their diameter).

Although much of the variation in biomass for pan-tropical models was explained by only diameter, the improvement was relatively significant when basic height and density were included (see Table 5). When analyzing the predictions of local and pantropical models, the variation in biomass estimated for small diameter trees is in fact smaller, being similarly predicted by models which include height or height and basic wood density. However, there is a great divergence for different diameter classes when height is not included in the prediction, which results in significantly higher percentage biases of those models that include height (Fig. 4).

Table 5 Accuracy and bias for biomass prediction from pan-tropical models with dry tropical forest, northeastern Brazil.

\begin{tabular}{llccccc}
\hline \multicolumn{1}{c}{ Equations } & scale & variable & Pseudo-R & RMSE & Bias & CV\% \\
\hline Brown et al. (1989) & Pan-tropical & $\mathrm{Db}$ & 0,9023 & 16,0791 & 7,5796 & 297,99 \\
Brown et al. (1997) & Pan-tropical & $\mathrm{Db}$ & 0,8982 & 14,7558 & 0,9086 & 301,47 \\
Návar (2015) & Pan-tropical & $\mathrm{Db}$ & 0,9049 & 16,6454 & 0,3744 & 251,12 \\
Chave et al. (2005) - Type II.1 & Pan-tropical & $\mathrm{Db} / \mathrm{WD}$ & 0,8254 & 23,4906 & 2,1383 & 378,07 \\
Chave et al. (2005)- Type II.3 & Pan-tropical & $\mathrm{Db} / \mathrm{WD}$ & 0,6070 & 32,9759 & 2,5968 & 350,73 \\
Chave et al. (2005) - Type I.1 & Pan-tropical & $\mathrm{Db} / \mathrm{Ht} / \mathrm{WD}$ & 0,8080 & 25,1675 & 0,5028 & 181,96 \\
Chave et al. (2005) - Type I.5 & Pan-tropical & $\mathrm{Db} / \mathrm{Ht} / \mathrm{WD}$ & 0,6434 & 28,3263 & 0,4917 & 191,58 \\
Sampaio and Silva (2005) & Local & $\mathrm{Db} / \mathrm{Ht}$ & 0,8662 & 18,8651 & 0,3236 & 242,37 \\
Dalla-Lana et al. (2018) & Local & $\mathrm{Db} / \mathrm{Ht}$ & 0,8222 & 28,0706 & 1,1956 & 146,38 \\
Barreto et al. (2018) & Local & $\mathrm{Db} / \mathrm{Ht}$ & 0,8185 & 27,3953 & 1,3992 & 154,21 \\
\hline
\end{tabular}



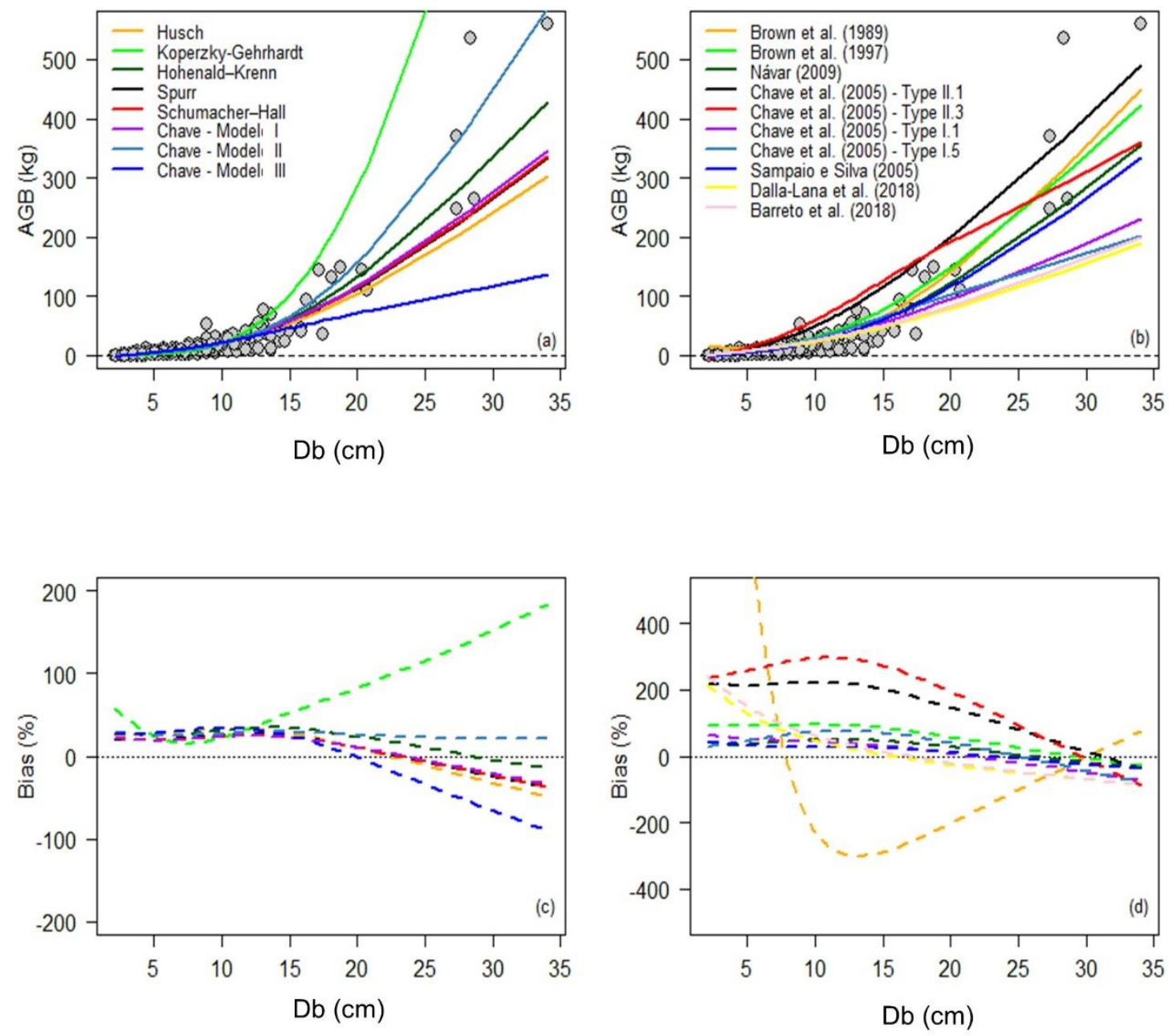

Fig. 4 Biomass prediction from the equations developed for the site (a) and from other local and pan-tropical equations (b); and percentage difference (bias) of biomass predictions at tree level by diameter class for local equations (c) and other local and pantropical equations (d).

When compared with the equations developed in this study, the average errors (RMSE and Bias) of the biomass estimate of the pan-tropical equations validated at the tree level did not reveal substantially visible differences, with the exception of the local Koperzky-Gehrhardt equation (Table 4) and the pan-tropical equation by Brown et al. 161 (1989) (Table 5) who use only the diameter as a predictor variable. The highest mean $\mathrm{CV}_{(\mathrm{i})}$ in all comparisons was $378 \%$ for the equation that uses wood density and diameter (Chave et al. 2005 - Type II.1) despite the Brown et al. (1989) reported a greater absolute 
error at the tree level (bias $=7.57 \mathrm{~kg}$ ). The mean lower bias was $0.32 \mathrm{~kg}$ for the Sampaio and Silva (2005) equation, which presents the same structure as the model developed locally.

For pan-tropical equations, these results reflect not only absolute values, but also a large percentage variation, especially when wood density is included along with diameter and height in biomass forecasts. Interestingly, however, in these equations the RMSE values practically double when compared to the equations of other tropical regions that use only the diameter or diameter and basic density.

The local equations developed tend to predict the AGB values in a more homogeneous manner and with a smaller amplitude of error for trees of smaller diameter, with a slight divergence for trees with $\mathrm{Db}>15 \mathrm{~cm}$ (bias $>30 \%$, Fig. 4c). Pan-tropical and local equations from other regions suggest greater differences by class of diameter, being substantially more visible in smaller trees mainly by the equation of Brown et al. (1989) (Fig. 4d). With the exception of the equations of Brown et al. (1989) and Barreto et al. (2018), the average biomass measured in the field does not report visible differences between the best local equations developed and the local equations of Dalla-Lana and pantropical of Navar (2015).

\section{Discussion}

Logarithmic models have constantly been used in the study of biometric relationships, mainly for developing biomass equations in dry tropical forests (Brown et al. 1989; Packard and Boardman 2008; Ubuy et al. 2018). These results are also in line with studies carried out in dry tropical forests in Brazil (Brahma et al. 2018; Roitman et al. 2018) and another regions tropical dry forest (Návar-Cháidez 2010; Abich et al. 2018). 
The base diameter and the total height of the tree were generally the best predictive biometric variables to estimate AGB. All the statistical evaluation criteria revealed that the double entry equations suggest greater precision of predictions, especially the equation obtained from the Schumacher-Hall model. These results indicate the inclusion of the height variable in the biomass estimate, as the simple entry models assume that trees of different diameters have the same heights, which is not true for dry tropical forests (Helmer et al. 2010; Salas-Morales et al. 2018). The functional form of the generated equation is biologically consistent, especially with the inclusion of the height variable, therefore it is concluded that tree height is an important biomass predictor, especially when considering data from different species (Abich et al. 2018).

Although height measurements are more expensive and time-consuming in forest inventories, the use of models which relate height and diameter is recommended in tropical forests (Feldpausch et al. 2011, 2012; Sullivan et al. 2018). Models which include tree height improve the biomass estimate in many tropical forests and support more accurate biomass and carbon estimates (Rutishauser et al. 2013).

However, it is important to note that the predominant tree forms are represented among the sample trees used to develop allometric and hypsometric models (Duncanson et al. 2015). The accuracy of biomass predictions is likely to be improved with appropriate sample trees and small measurement errors by adding height as an explanatory variable, despite the uncertainty added using a diameter height model (Larjavaara and MullerLandau 2013; Sullivan et al. 2018).

The biomass predictions by the best pan-tropical models suggest that its shape parameters and trunk profile ( $\square 1$ and $\square 2$ ) were not substantially different from the parameter estimates of the best local model. This indicates that biomass does not vary much on a pan-tropical scale, and that the local model of this study could be applied in 
other parts of dry forests in the tropics. These results may also explain that there is a similarity in the type of vegetation with different land use histories, due to bioclimatic conditions and soil types; or intrinsic characteristics of the tree, such as physiology, regrowth, adaptive development and trunk bifurcations (multiple stem species) (Chave et al. 2014).

This work seeks to fill the gap on the validity of allometric equations developed for dry tropical forests, although some research has already suggested the development of individual equations for species and regions (Chave et al. 2014; Lima et al. 2017). In addition to the importance of height measurements, the question currently being discussed in this paper is whether it would be better to use generic equations from other locations in locations where no generic allometric equation is available, or to develop locationspecific equations.

Another important point that must be considered for the development of equations is related to the intra and interspecific factors of the species, such as variations in the basic wood density (Henry et al. 2010; Bastin et al. 2015; Ali and Mattsson 2018); the tree canopy (Duncanson et al. 2010; Gara et al. 2014; Bastin et al. 2014; Salas-Morales et al. 2018), leaf area index and height profiles (Helmer et al. 2010; Greaves et al. 2015; Wagner et al. 2016; Cushman and Kellner 2019). Considering that such factors may still be influenced by changes in structural parameters such as richness, density, frequency and dominance, the development of specific allometric equations for locations and even more at the species level is fundamental for understanding the concentration of carbon stocks (Abich et al. 2018).

However, the development of allometric models is not a trivial task. The limiting factor has always been destructive sampling of the trees for adjusting and selecting the models. Highly accurate volume and biomass estimates of individual trees are 
increasingly available through Lidar technology (Estornell et al. 2011, 2012; Hildebrandt and Iost 2012). These estimates do not require destructive sampling of trees and can be carried out systematically in the field (Duncanson et al. 2017; Duncanson and Dubayah 2018). A system could be developed with proper sampling to sample biometric data in situ from the tree in environmental gradients, providing a potential solution to the outstanding problems related to forest biomass and carbon stock.

\section{Conclusions}

The statistical results of the selected models were satisfactory and the evaluations revealed that the equations which include height in the biomass forecasts are more accurate than the models without height, and this statement is valid for the pan-tropical models with height when a local equation is not available. Predictive errors generally observed when testing and validating local and "pan-tropical" models without height demonstrated the importance of developing new models including the total height of trees. The large forecasting errors for "pan-tropical" models without height also indicate that careful considerations should be made if they are planned to be applied to dry forests elsewhere in northeastern Brazil. As there are no other appropriate model options, it is by the Schumacher-Hall equation: $e^{3.5336+1.9126 \times \log (\mathrm{D})+1.2438 \times \log (\mathrm{Ht})}$. The development of local allometric equations is appropriate to improve the above-ground biomass (AGB) estimates in the dry tropical forests of Pernambuco, Brazil. It is a vital step in the ecosystem assessment of forest resources. This forest is widely recognized as one of the main ecosystems for carbon sequestration and desertification barriers. They can serve as 
263 important tools for carbon credit and payment for environmental services initiatives. As

264 revealed in this study, the base diameter and height are the best biomass estimators,

265 representing more than $90 \%$ of the AGB for multi-species data. The comparison of

266 equations showed that the pan-tropical equation for dry forests developed by Chave et al.

267 (2005) can be used for the evaluation of forest biomass when the specific equations of the

268 place and species are absent. Thus, the equations can be used for carbon accounting in

269 REDD + and appropriate incentive projects which initiate forest development and

270 evaluate ecosystem services.

271

272 Material and methods

273 Study area and collected data

274 The data used in the present study were collected from trees harvested from an area

275 submitted to forest management located in the municipality of Floresta, State of 276 Pernambuco $\left(8^{\circ} 30^{\prime} 37^{\prime \prime} \mathrm{S}\right.$ and $\left.37^{\circ} 59^{\prime} 07^{\prime \prime} \mathrm{W}\right)$. The vegetation is predominantly Caatinga

277 (tropical dry forest) characterized by shrub-tree vegetation, with the presence of cacti and 278 herbaceous strata (IBGE, 2012) (Fig. 1). 

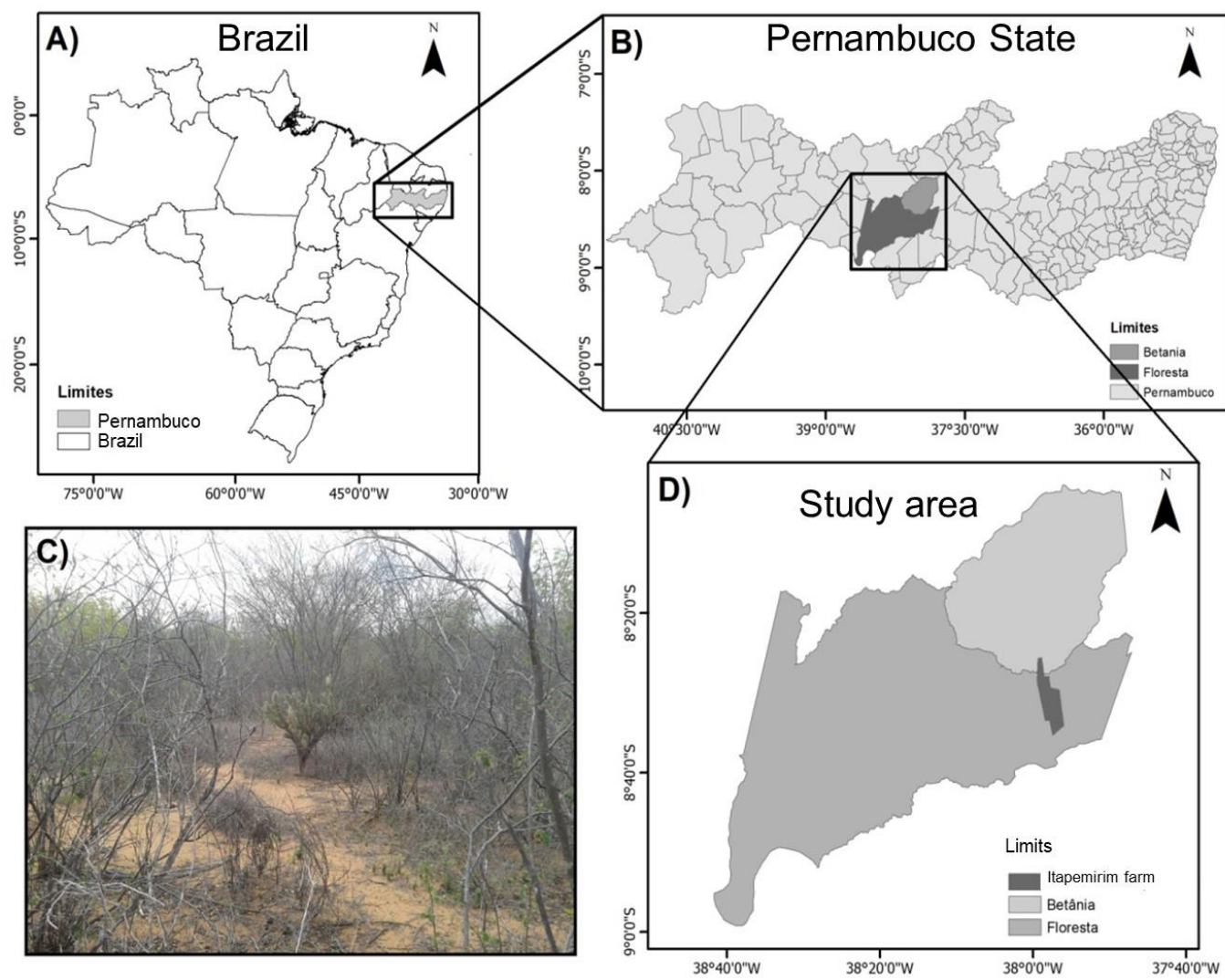

Fig. 1 Coverage of the study area: A, B and D, and profile photo in Floresta C, in the

hinterland of Pernambuco, Brazil.

The two study areas differ from each other in terms of preservation conditions.

The first to the north is called "transposition" with 40 permanent plots of $400 \mathrm{~m}^{2}(20 \times 20$ $\mathrm{m}$ ), having an extension of approximately 50 ha and is considered preserved (55 years of lesser anthropic disorders). The second area further south, also with 40 permanent plots of $400 \mathrm{~m}^{2}(20 \times 20 \mathrm{~m})$ called "correntão", underwent logging using the correntão technique in 1987 for planting eucalyptus, but was abandoned and has been undergoing regeneration for 29 years (Fig. 2). 


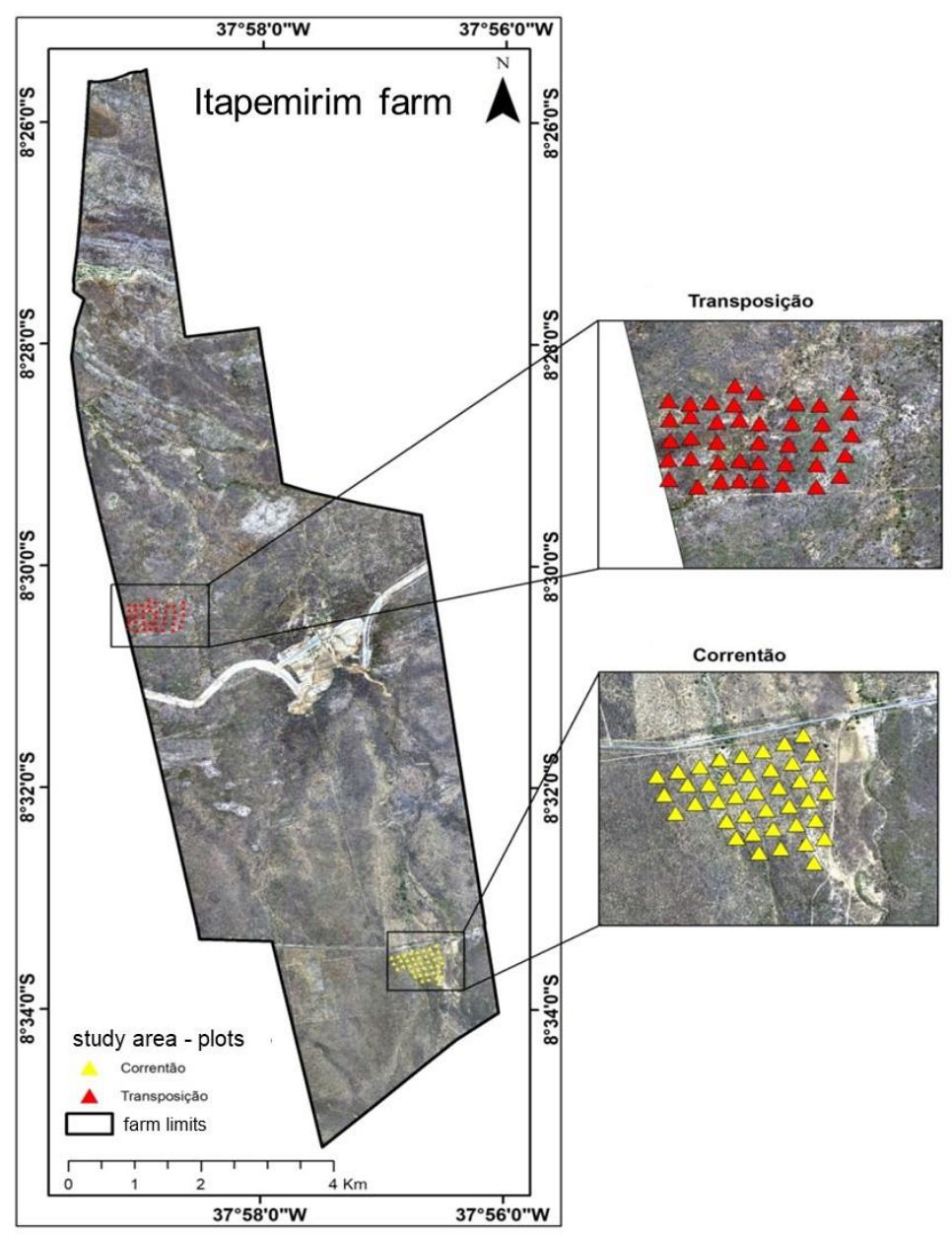

290 Fig. 2 Sampling procedure used in the two inventoried areas in the Municipality of 291 Floresta, Pernambuco

The aboveground biomass (trunk and branches), total and commercial heights and base diameter $(0.30 \mathrm{~cm}$ from ground level $)$ and diameter at breast height $(1.30 \mathrm{~cm}$ from ground level) of 507 trees distributed in 14 species and 2 genera were measured. The trees were harvested with a minimum diameter at the base of the stem $(\mathrm{Db})$ of $1.9 \mathrm{~cm}$, up to the maximum found in the area, and covered a wide sampling range for diameter and 297 heights. Table 1 has a descriptive summary with the means, maximums and minimums 298 for the variables of the measured species. We consider the local values of basic wood density of the species, and when not available, the global database (Chave et al. 2014) available at https://datadryad.org/handle/10255/dryad.235 was considered. Despite the 
301 lack of sufficient data, several studies recommend average wood density at the gender

302 level for biomass assessment (Henry et al. 2010; Ubuy et al. 2018).

303 Table 1 Dendrometric variables of dry tropical forest species, in northeastern Brazil, used 304 to develop local biomass equations.

\begin{tabular}{|c|c|c|c|c|c|c|c|c|c|c|c|}
\hline \multirow{2}{*}{ Espécies } & \multirow{2}{*}{$\mathrm{n}$} & \multirow[t]{2}{*}{ WD } & \multicolumn{3}{|c|}{$\mathrm{Db}$} & \multicolumn{3}{|c|}{$\mathrm{Ht}$} & \multicolumn{3}{|c|}{ AGB } \\
\hline & & & Min & Mean & Max & Min & Mean & Max & Min & Mean & Max \\
\hline Anadenanthera colubrina & 17 & 0.79 & 2.55 & 8.57 & 18.78 & 3.20 & 5.61 & 8.00 & 1.30 & 44.16 & 145.00 \\
\hline Aspidosperma pyrifolium & 45 & 0.74 & 2.07 & 4.60 & 9.55 & 2.50 & 3.84 & 5.40 & 0.50 & 7.92 & 52.00 \\
\hline Cnidoscolus phyllacanthus & 5 & 0.55 & 7.32 & 12.29 & 17.19 & 5.80 & 6.58 & 7.60 & 17.00 & 71.90 & 132.00 \\
\hline Commiphora leptophloeos & 7 & 0.39 & 6.37 & 17.37 & 27.37 & 4.20 & 6.30 & 8.30 & 17.00 & 215.71 & 536.00 \\
\hline Croton spp. & 68 & 0.59 & 1.91 & 2.58 & 6.37 & 2.00 & 3.27 & 5.20 & 0.25 & 1.55 & 11.00 \\
\hline Mimosa ophthalmocentra & 81 & 0.71 & 1.91 & 3.33 & 5.09 & 3.00 & 3.89 & 5.40 & 0.30 & 3.72 & 16.00 \\
\hline Mimosa tenuiflora & 22 & 1.12 & 2.23 & 7.22 & 16.87 & 3.20 & 5.43 & 9.10 & 1.50 & 26.90 & 149.00 \\
\hline Piptadenia stipulacea & 21 & 0.74 & 2.07 & 3.93 & 7.00 & 3.40 & 5.24 & 8.80 & 0.50 & 6.87 & 23.00 \\
\hline Poincianella bracteosa & 202 & 0.99 & 1.91 & 4.96 & 14.48 & 2.10 & 4.02 & 6.80 & 0.50 & 8.35 & 45.00 \\
\hline Erythrostemon calycina & 3 & 1.01 & 2.23 & 2.33 & 2.55 & 3.40 & 3.57 & 3.70 & 0.50 & 0.97 & 1.30 \\
\hline
\end{tabular}

305 where $\mathrm{n}$ is number of trees harvested, WD is mean wood basic density of individual trees

$306\left(\mathrm{~g} \mathrm{~cm}^{-3}\right), \mathrm{Db}$ is diameter at stump height $(\mathrm{cm}), \mathrm{Ht}$ is total tree height $(\mathrm{m})$, AGB is total 307 aboveground tree biomass $(\mathrm{kg})$.

\section{Model fitting and validation}

310 The biometric data were randomly divided into two subsets after measurement for fitting and validating the allometric models using the Hold-out, cross-validation tool which randomly selects a sample $\mathrm{N} 1=80 \%$ to adjust the models and $\mathrm{N} 2=20 \%$ to validate the models.

Three single-entry allometric models (with only the base diameter as an explanatory variable) and five double-entry models were tested, with the explanatory variables being $\mathrm{Db}$ and total height (later referred to as locally derived models, Table 2).

Table 2 Allometric models tested to estimate above-ground biomass in a dry tropical forest in the semi-arid region of Pernambuco, Brazil.

\begin{tabular}{lrc}
\hline Autor & Model & Variables \\
\hline 1. Husch & 1.AGB $=\exp \left(\beta_{0}+\beta_{1} \times \operatorname{Ln}(\mathrm{D})+\varepsilon_{i}\right)$ & $\mathrm{AGB}=\mathrm{f}(\mathrm{Db})$ \\
\hline
\end{tabular}




\begin{tabular}{|c|c|c|}
\hline 2. Koperzky-Gehrhardt & 2. $\mathrm{AGB}=\exp \left(\beta_{0}+\beta_{1} \times \operatorname{Ln}(\mathrm{D})^{2}+\varepsilon_{i}\right)$ & $\mathrm{AGB}=\mathrm{f}(\mathrm{Db})$ \\
\hline 3. Hohenald-Krenn & 3. $\mathrm{AGB}=\exp \left(\beta_{0}+\beta_{1} \times \operatorname{Ln}(\mathrm{D})+\beta_{2} \times \operatorname{Ln}(\mathrm{D})^{2}+\varepsilon_{i}\right)$ & $\mathrm{AGB}=\mathrm{f}(\mathrm{Db})$ \\
\hline 4. Spurr & 4. $A G B=\exp \left(\beta_{0}+\beta_{1} \times \operatorname{Ln}\left(D^{2} \times H t\right)\right)$ & $\mathrm{AGB}=\mathrm{f}(\mathrm{Db}, \mathrm{Ht})$ \\
\hline 5. Schumacher-Hall (1933) & 5. AGB $=\exp \left(\beta_{0}+\beta_{1} \times \operatorname{Ln}(\mathrm{D})+\beta_{2} \times \operatorname{Ln}(\mathrm{Ht})+\varepsilon_{i}\right)$ & $\mathrm{AGB}=\mathrm{f}(\mathrm{Db}, \mathrm{Ht})$ \\
\hline 6. Chave et al. (2005) - model I & $\begin{aligned} 6 . \mathrm{AGB}=\exp \left(\beta_{0}+\right. & \beta_{1} \times \operatorname{Ln}(\mathrm{D})+\beta_{2} \times \operatorname{Ln}(\mathrm{Ht}) \\
& \left.+\beta_{3} \times \operatorname{Ln}(\mathrm{WD})+\varepsilon_{i}\right)\end{aligned}$ & $\mathrm{AGB}=\mathrm{f}(\mathrm{Db}, \mathrm{Ht}, \mathrm{WD})$ \\
\hline 7. Chave et al. (2005) - model II & 7. $\begin{aligned} \mathrm{AGB}=\exp \left(\beta_{0}+\right. & \beta_{1} \times \operatorname{Ln}(\mathrm{D})+\beta_{2} \times \operatorname{Ln}(\mathrm{D})^{2} \\
& \left.+\beta_{3} \times \operatorname{Ln}(\mathrm{D})^{3}+\beta_{4} \times \operatorname{Ln}(\mathrm{WD})+\varepsilon_{i}\right)\end{aligned}$ & $\mathrm{AGB}=\mathrm{f}(\mathrm{Db}, \mathrm{WD})$ \\
\hline 8. Chave et al. (2005) - model III & 8. $A G B=\exp \left(\beta_{0}+\beta_{1} \times \operatorname{Ln}\left(D^{2} \times H t \times W D\right)+\varepsilon_{i}\right)$ & $\mathrm{AGB}=\mathrm{f}(\mathrm{Db}, \mathrm{Ht}, \mathrm{WD})$ \\
\hline
\end{tabular}

where $\beta_{i}=$ parameters to be estimated; $\varepsilon_{i}=$ random error.

We estimate model parameters using the Ordinary Least Squares (OLS) method

and we verified the significance using the $t$ test $(\mathrm{p}=0.05)$. The parameters were generally

calculated using the total data of the trees measured and are assumed to be the true

parameters which represent allometry. However, samples (20\%) were extracted from the complete data set to assess the influence of predictions and calculate the bias of the estimates with the adjusted parameters (Hold-out). The purpose of this tool is to estimate the value of a set of evaluation statistics using cross-validation testing. This type of estimate is obtained by performing $\mathrm{N}$ repetitions of a test cycle, where $\mathrm{N}$ is the size of the data set provided. One of the $\mathrm{N}$ observations is left out in each repetition to serve as a test set, while the remaining N-1 cases are used to obtain the model (James et al. 2013). The process is repeated $\mathrm{N}$ times, setting aside each of the $\mathrm{N}$ observations given. The Hold-out estimates are obtained by the average of the $\mathrm{N}$ scores obtained in the different repetitions. All computations and analyzes were performed using the $\mathrm{R}^{\circledR}$ statistical software $(\mathrm{R}$ Development Core Team, 2019). this variable on the biomass predictions at the tree level. All the generated equations were analyzed by comparing the following statistical criteria: 
$337 \quad \mathrm{RMSE}=\sqrt{\frac{\sum_{\mathrm{i}=1}^{\mathrm{n}}\left(\mathrm{AGB}_{\mathrm{i}}-\overline{\mathrm{AGB}}_{\mathrm{i}}\right)^{2}}{\mathrm{n}}}$

$338 \quad$ Bias $=\frac{\sum_{\mathrm{i}=1}^{\mathrm{n}}\left(\mathrm{AGB}_{\mathrm{i}}-\overline{\mathrm{AGB}}_{\mathrm{i}}\right)^{2}}{\mathrm{n}} / \overline{\mathrm{AGB}}$

where $A G B_{i}$ is aboveground biomass (i); $\overline{\mathrm{AGB}}_{i}$ is the estimate of aboveground biomass and $n$ is the total number of observations. $\overline{\mathrm{AGB}}_{\mathrm{i}}$ is mean aboveground biomass.

\section{Allometric predictions}

The local equations developed in this study were compared with generic local/pantropical equations developed for dry forest areas using only diameter, or and in combination with height (Ht) and wood density (wd) as predictor variables (Table 3).

Table 3 Generic allometric equations of local and pantropical scope used to estimate the above ground biomass $(\mathrm{kg})$ in dry tropical forest based on diameter $(\mathrm{Db}, \mathrm{cm})$, height $(\mathrm{Ht}$, $\mathrm{m})$ and basic wood density $\left(\mathrm{WD}, \mathrm{gcm}^{3}\right)$.

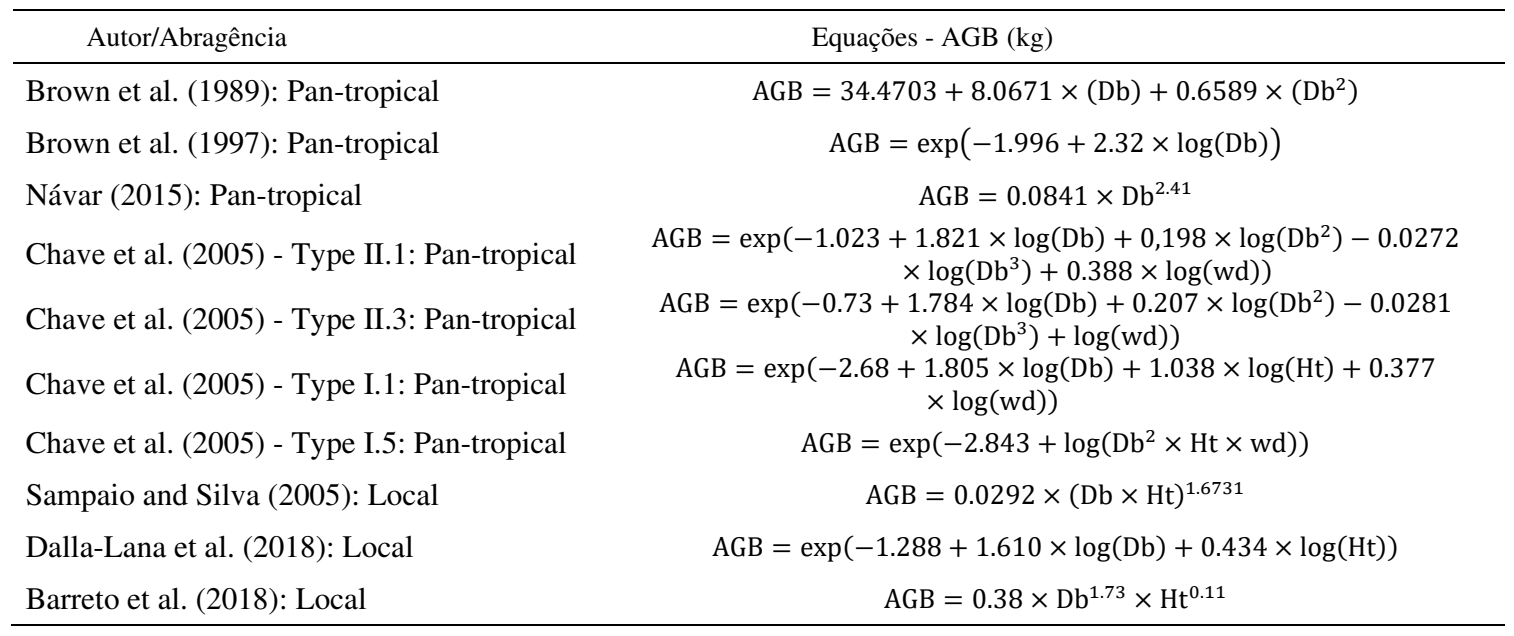

These pan-tropical allometric equations developed for dry tropical forests were applied to the sample trees in this study and are widely applied to predict stock assessments of $\mathrm{AGB}$ and $\mathrm{C}$ in dry tropical regions (ABICH et al., 2018). We compared the observed average AGB and the predicted AGB. 
351 The model error (RSE) and the tree level variation coefficient (CV) were defined for each

352 equation as follows:

$353 \quad \mathrm{RSE}=\frac{1}{\mathrm{~N}} \sum_{\mathrm{i}=1}^{\mathrm{N}}\left[\mathrm{AGB}_{\mathrm{ALTi}}-\mathrm{AGB}_{\mathrm{REFi}}\right] / \mathrm{AGB}_{\mathrm{REFi}}$

$354 \quad \overline{\operatorname{AGB}}_{(\mathrm{i})}=\frac{1}{\mathrm{~N}_{(\mathrm{j})}} \sum_{\mathrm{i} \in(\mathrm{j})} \mathrm{AGB}_{\mathrm{REF}}(\mathrm{i})$

$355 \quad \mathrm{CV}(\mathrm{i}) \%=\frac{\mathrm{RSE}(\mathrm{i})}{\overline{\mathrm{AGB}}(\mathrm{i})} \times 100$

In which: $\mathrm{AGB}_{\mathrm{ALTi}}$ and $\mathrm{AGB}_{\mathrm{REFi}}$ are the biomass estimate of tree $i$ obtained from alternative equations with and without height (pan-tropical) and reference (local models with and without height), respectively. A large CV value (i) would be acceptable as long as the bias is low, because the model is generally applied to many trees within a site and therefore random errors tend to cancel each other out (Chave et al. 2014).

We also calculated new measures of mean prediction errors (bias) and in addition, the models were evaluated based on Pseudo- $\mathrm{R}^{2}$ as follows:

Pseudo $-\mathrm{R}_{\mathrm{aj}}^{2}=1-\frac{\mathrm{SSR}}{\sum_{\mathrm{i}=1}^{\mathrm{N}}\left(\mathrm{AGB}_{\mathrm{i}}-\overline{\mathrm{AGB}}_{\mathrm{i}}\right)}$

\section{List of abbreviations}

IBGE - Instituto Brasileiro de Geografia e Estatística

Availability of data and materials

The data are available upon a reasonable request to the Authors.

$370 \quad$ Not applicable.

\section{Consent for publication}

372 Not applicable.

\section{Competing interests}

374 The authors declare no conflict of interest 
Not applicable.

377

\section{Authors' contributions}

Cinthia Oliveira and Rinaldo Ferreira planned the study and wrote the manuscript,

Robson Lima and José Aleixo da Silva participated in the processing, calculation and modeling of the data and wrote the manuscript. Francisco Alves Júnior Emanuel Silva collected and processed the data. They also commented on the manuscript. The authors read and approved the final manuscript.

Acknowledgements

The authors are grateful for the help of the researchers Rinaldo Caraciolo Ferreira, José

Aleixo da Silva and Robson Lima who collaborated to complete this work. We also thank the forestry worker and German Cespedez, who is responsible for the data access to the productivity bag of the second and third co-authors, project leaders. by the National Council for Scientific and Technological Development (CNPq) by the

\section{References}

Abich A, Mucheye T, Tebikew M, et al (2018) Species-specific allometric equations for improving aboveground biomass estimates of dry deciduous woodland ecosystems. J For Res. https://doi.org/10.1007/s11676-018-0707-5

Ali A, Mattsson E (2018) Wood density is a sustainability indicator for the management of dry zone homegarden agroforests: Evidences from biodiversity-ecosystem function relationships. Ecol Indic. https://doi.org/10.1016/j.ecolind.2018.04.024

Althoff TD, Menezes RSC, Pinto A de S, et al (2018) Adaptation of the century model to simulate $\mathrm{C}$ and $\mathrm{N}$ dynamics of Caatinga dry forest before and after deforestation. Agric Ecosyst Environ 254:26-34. https://doi.org/10.1016/j.agee.2017.11.016 
Avitabile V, Camia A (2018) An assessment of forest biomass maps in Europe using harmonized national statistics and inventory plots. For Ecol Manag 409:489-498. https://doi.org/10.1016/j.foreco.2017.11.047

Avitabile V, Herold M, Heuvelink GBM, et al (2016) An integrated pan-tropical biomass map using multiple reference datasets. Glob Change Biol 22:1406-1420. https://doi.org/10.1111/gcb.13139

Baccini A, Asner GP (2013) Improving pantropical forest carbon maps with airborne LiDAR sampling. Carbon Manag 4:591-600. https://doi.org/10.4155/cmt.13.66

Bastin J-F, Barbier N, Couteron P, et al (2014) Aboveground biomass mapping of African forest mosaics using canopy texture analysis: toward a regional approach. Ecol Appl 24:1984-2001. https://doi.org/10.1890/13-1574.1

Bastin J-F, Berrahmouni N, Grainger A, et al (2017) The extent of forest in dryland biomes. Science 356:635-638. https://doi.org/10.1126/science.aam6527

Bastin J-F, Fayolle A, Tarelkin Y, et al (2015) Wood Specific Gravity Variations and Biomass of Central African Tree Species: The Simple Choice of the Outer Wood. PLOS ONE 10:e0142146. https://doi.org/10.1371/journal.pone.0142146

Bouvet A, Mermoz S, Le Toan T, et al (2018) An above-ground biomass map of African savannahs and woodlands at $25 \mathrm{~m}$ resolution derived from ALOS PALSAR. Remote Sens Environ 206:156-173. https://doi.org/10.1016/j.rse.2017.12.030

Brahma B, Nath AJ, Sileshi GW, Das AK (2018) Estimating biomass stocks and potential loss of biomass carbon through clear-felling of rubber plantations. Biomass Bioenergy 115:88-96. https://doi.org/10.1016/j.biombioe.2018.04.019

Brown S, Gillespie AJR, Lugo AE (1989) Biomass estimation methods for tropical forests with applications to forest inventory data. For Sci 35:881-902

Brown S (1997) Estimating biomass and biomass changing of tropical forests: a primer. Rome: FAO Forestry Paper

Chaturvedi RK, Raghubanshi AS (2015) Allometric Models for Accurate Estimation of Aboveground Biomass of Teak in Tropical Dry Forests of India. For Sci 61:938949. https://doi.org/10.5849/forsci.14-190

Chave J, Andalo C, Brown S, et al (2005a) Tree allometry and improved estimation of carbon stocks and balance in tropical forests. Oecologia 145:87-99. https://doi.org/10.1007/s00442-005-0100-x

Chave J, Andalo C, Brown S, et al (2005b) Tree allometry and improved estimation of carbon stocks and balance in tropical forests. Oecologia 145:87-99. https://doi.org/10.1007/s00442-005-0100-x

Chave J, Réjou-Méchain M, Búrquez A, et al (2014) Improved allometric models to estimate the aboveground biomass of tropical trees. Glob Change Biol 20:31773190. https://doi.org/10.1111/gcb.12629 
Cushman KC, Kellner JR (2019) Prediction of forest aboveground net primary production from high-resolution vertical leaf-area profiles. Ecol Lett 22:538-546. https://doi.org/10.1111/ele.13214

Dalla Lana M. et al. (2018) Biomass equations for caatinga species. Nativa 6:517-525. http://dx.doi.org/10.31413/nativa.v6i5.5361

Duncanson L, Dubayah R (2018) Monitoring individual tree-based change with airborne lidar. Ecol Evol 8:5079-5089. https://doi.org/10.1002/ece3.4075

Duncanson L, Huang W, Johnson K, et al (2017) Implications of allometric model selection for county-level biomass mapping. Carbon Balance Manag 12:. https://doi.org/10.1186/s13021-017-0086-9

Duncanson L, Rourke O, Dubayah R (2015) Small Sample Sizes Yield Biased Allometric Equations in Temperate Forests. Sci Rep 5:. https://doi.org/10.1038/srep17153

Duncanson LI, Niemann KO, Wulder MA (2010) Estimating forest canopy height and terrain relief from GLAS waveform metrics. Remote Sens Environ 114:138-154. https://doi.org/10.1016/j.rse.2009.08.018

Estornell J, Ruiz LA, Velázquez-Martí B, Fernández-Sarría A (2011) Estimation of shrub biomass by airborne LiDAR data in small forest stands. For Ecol Manag 262:1697-1703. https://doi.org/10.1016/j.foreco.2011.07.026

Estornell J, Ruiz LA, Velázquez-Martí B, Hermosilla T (2012) Estimation of biomass and volume of shrub vegetation using LiDAR and spectral data in a Mediterranean environment. Biomass Bioenergy 46:710-721. https://doi.org/10.1016/j.biombioe.2012.06.023

Feldpausch TR, Banin L, Phillips OL, et al (2011) Height-diameter allometry of tropical forest trees. Biogeosciences 8:1081-1106. https://doi.org/10.5194/bg-8-10812011

Feldpausch TR, Lloyd J, Lewis SL, et al (2012) Tree height integrated into pantropical forest biomass estimates. Biogeosciences 9:3381-3403. https://doi.org/10.5194/bg-9-3381-2012

Gara TW, Murwira A, Chivhenge E, et al (2014) Estimating wood volume from canopy area in deciduous woodlands of Zimbabwe. South For J For Sci 76:237-244. https://doi.org/10.2989/20702620.2014.965981

Gonzalez de Tanago J, Lau A, Bartholomeus H, et al (2018) Estimation of above-ground biomass of large tropical trees with terrestrial LiDAR. Methods Ecol Evol 9:223234. https://doi.org/10.1111/2041-210X.12904

Greaves HE, Vierling LA, Eitel JUH, et al (2015) Estimating aboveground biomass and leaf area of low-stature Arctic shrubs with terrestrial LiDAR. Remote Sens Environ 164:26-35. https://doi.org/10.1016/j.rse.2015.02.023 
Guha S, Pal T, Nath DS, Das B (2019) Comparison of Biomass in Natural and Plantation Dry Forests in India. In: Pradhan B (ed) GCEC 2017. Springer Singapore, Singapore, pp 995-1006

Helmer EH, Ruzycki TS, Wunderle JM, et al (2010) Mapping tropical dry forest height, foliage height profiles and disturbance type and age with a time series of cloudcleared Landsat and ALI image mosaics to characterize avian habitat. Remote Sens Environ 114:2457-2473. https://doi.org/10.1016/j.rse.2010.05.021

Henry M, Besnard A, Asante WA, et al (2010) Wood density, phytomass variations within and among trees, and allometric equations in a tropical rainforest of Africa. For Ecol Manag 260:1375-1388. https://doi.org/10.1016/j.foreco.2010.07.040

Hildebrandt R, Iost A (2012) From points to numbers: a database-driven approach to convert terrestrial LiDAR point clouds to tree volumes. Eur J For Res 131:18571867. https://doi.org/10.1007/s10342-012-0638-1

Hiltner U, Huth A, Bräuning A, et al (2018) Simulation of succession in a neotropical forest: High selective logging intensities prolong the recovery times of ecosystem functions. For Ecol Manag 430:517-525. https://doi.org/10.1016/j.foreco.2018.08.042

Instituto Brasileiro de Geografia e Estatística- IBGE (2012) Manual técnico da vegetação brasileira.

James G, Witten D, Hastie T, Tibshirani R (2013) An Introduction to Statistical Learning. Springer New York, New York, NY

Jucker T, Caspersen J, Chave J, et al (2017) Allometric equations for integrating remote sensing imagery into forest monitoring programmes. Glob Change Biol 23:177190. https://doi.org/10.1111/gcb.13388

Kachamba D, Ørka H, Næsset E, et al (2017) Influence of Plot Size on Efficiency of Biomass Estimates in Inventories of Dry Tropical Forests Assisted by Photogrammetric Data from an Unmanned Aircraft System. Remote Sens 9:610. https://doi.org/10.3390/rs9060610

Larjavaara M, Muller-Landau HC (2013) Measuring tree height: a quantitative comparison of two common field methods in a moist tropical forest. Methods Ecol Evol 4:793-801. https://doi.org/10.1111/2041-210X.12071

Lima RBD, Alves Júnior FT, Oliveira CPD, et al (2017) Predicting of biomass in Brazilian tropical dry forest: a statistical evaluation of generic equations. An Acad Bras Ciênc 89:1815-1828. https://doi.org/10.1590/0001-3765201720170047

Návar J (2015) Pan tropical biomass equations for Mexico's dry forests. Agron Colomb 32:367-376. https://doi.org/10.15446/agron.colomb.v32n3.45627

Návar J, Ríos-Saucedo J, Pérez-Verdín G, et al (2013) Regional aboveground biomass equations for North American arid and semi-arid forests. J Arid Environ 97:127135. https://doi.org/10.1016/j.jaridenv.2013.05.016 
Návar-Cháidez J (2010) Biomass allometry for tree species of northwestern Mexico. Trop. $\quad$ Subtrop. $\quad$ Agroecosystems 12: 507-519. http://www.revista.ccba.uady.mx/urn:ISSN:1870-0462-tsaes.v12i3.391

Packard GC, Boardman TJ (2008) Model Selection and Logarithmic Transformation in Allometric Analysis. Physiol Biochem Zool 81:496-507. https://doi.org/10.1086/589110

Pelletier J, Siampale A, Legendre P, et al (2017) Human and natural controls of the variation in aboveground tree biomass in African dry tropical forests. Ecol Appl 27:1578-1593. https://doi.org/10.1002/eap.1550

R Core Team (2019) R: a language and environment for statistical computing. R Foundation for Statistical Computing, Vienna https://www.R-project.org/

Roitman I, Bustamante MMC, Haidar RF, et al (2018) Optimizing biomass estimates of savanna woodland at different spatial scales in the Brazilian Cerrado: Reevaluating allometric equations and environmental influences. PLOS ONE 13:e0196742. https://doi.org/10.1371/journal.pone.0196742

Rutishauser E, Noor'an F, Laumonier Y, et al (2013) Generic allometric models including height best estimate forest biomass and carbon stocks in Indonesia. For Ecol Manag 307:219-225. https://doi.org/10.1016/j.foreco.2013.07.013

Salas-Morales SH, González EJ, Meave JA (2018) Canopy height variation and environmental heterogeneity in the tropical dry forests of coastal Oaxaca, Mexico. Biotropica 50:26-38. https://doi.org/10.1111/btp.12491

Salinas-Melgoza MA, Skutsch M, Lovett JC (2018) Predicting aboveground forest biomass with topographic variables in human-impacted tropical dry forest landscapes. Ecosphere 9:e02063. https://doi.org/10.1002/ecs2.2063

Salis SM, Assis MA, Mattos PP, Pião ACS (2006) Estimating the aboveground biomass and wood volume of savanna woodlands in Brazil's Pantanal wetlands based on allometric correlations. For Ecol Manag 228:61-68. https://doi.org/10.1016/j.foreco.2006.02.025

Sampaio E, Gasson P, Baracat A, et al (2010) Tree biomass estimation in regenerating areas of tropical dry vegetation in northeast Brazil. For Ecol Manag 259:11351140. https://doi.org/10.1016/j.foreco.2009.12.028

Sampaio EVSB, Silva GC (2005) Biomass equations for Brazilian semiarid caatinga plants. Acta Bot Bras 19:935-943. https://doi.org/10.1590/S010233062005000400028

Sullivan MJP, Lewis SL, Hubau W, et al (2018) Field methods for sampling tree height for tropical forest biomass estimation. Methods Ecol Evol 9:1179-1189. https://doi.org/10.1111/2041-210X.12962

Ubuy MH, Eid T, Bollandsås OM, Birhane E (2018) Aboveground biomass models for trees and shrubs of exclosures in the drylands of Tigray, northern Ethiopia. J Arid Environ 156:9-18. https://doi.org/10.1016/j.jaridenv.2018.05.007 
557 Wagner FH, Hérault B, Bonal D, et al (2016) Climate seasonality limits leaf carbon assimilation and wood productivity in tropical forests. Biogeosciences 13:25372562. https://doi.org/10.5194/bg-13-2537-2016

560 
Figures

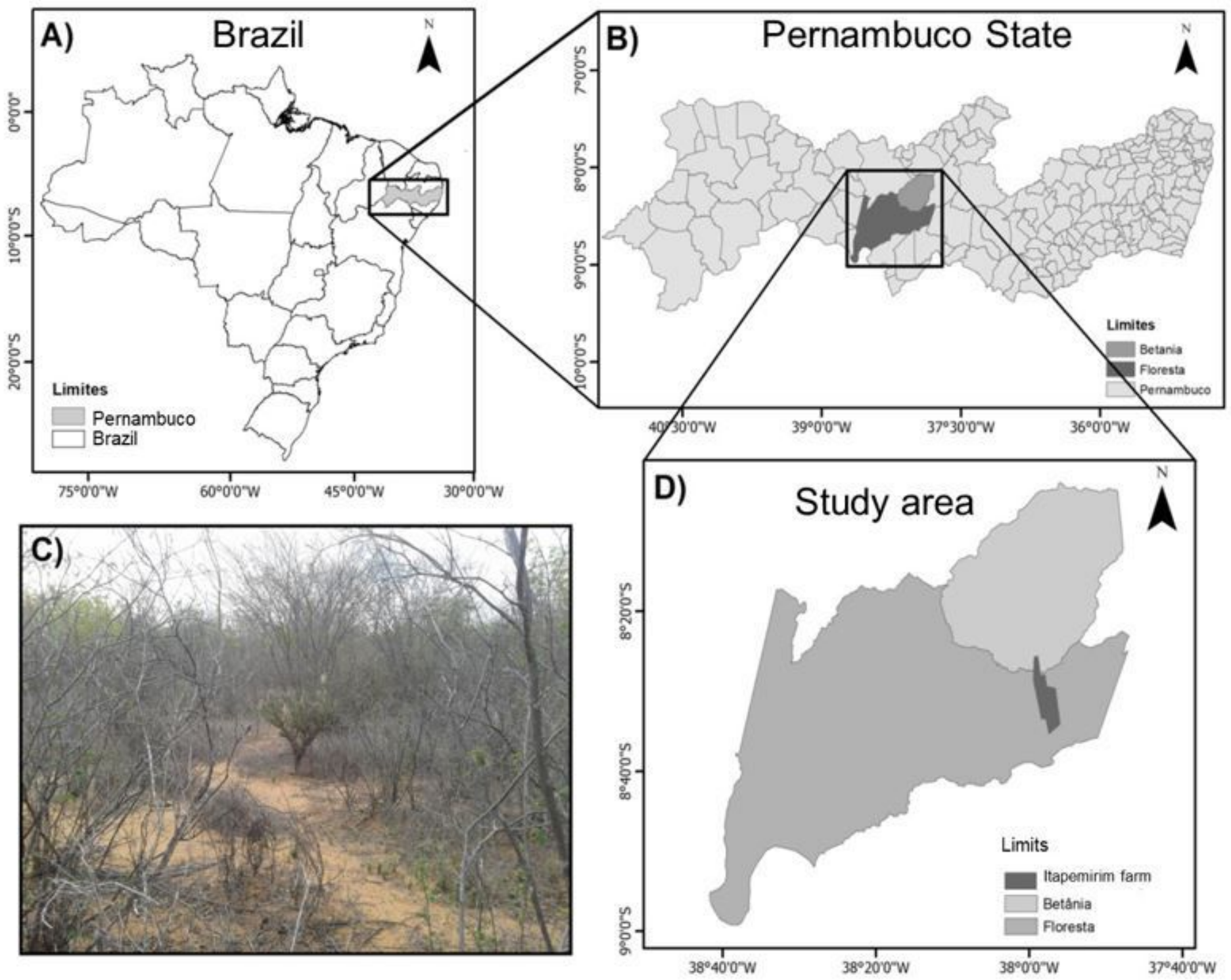

Figure 1

Coverage of the study area: A, B and D, and profile photo in Floresta C, in the hinterland of Pernambuco, Brazil. 


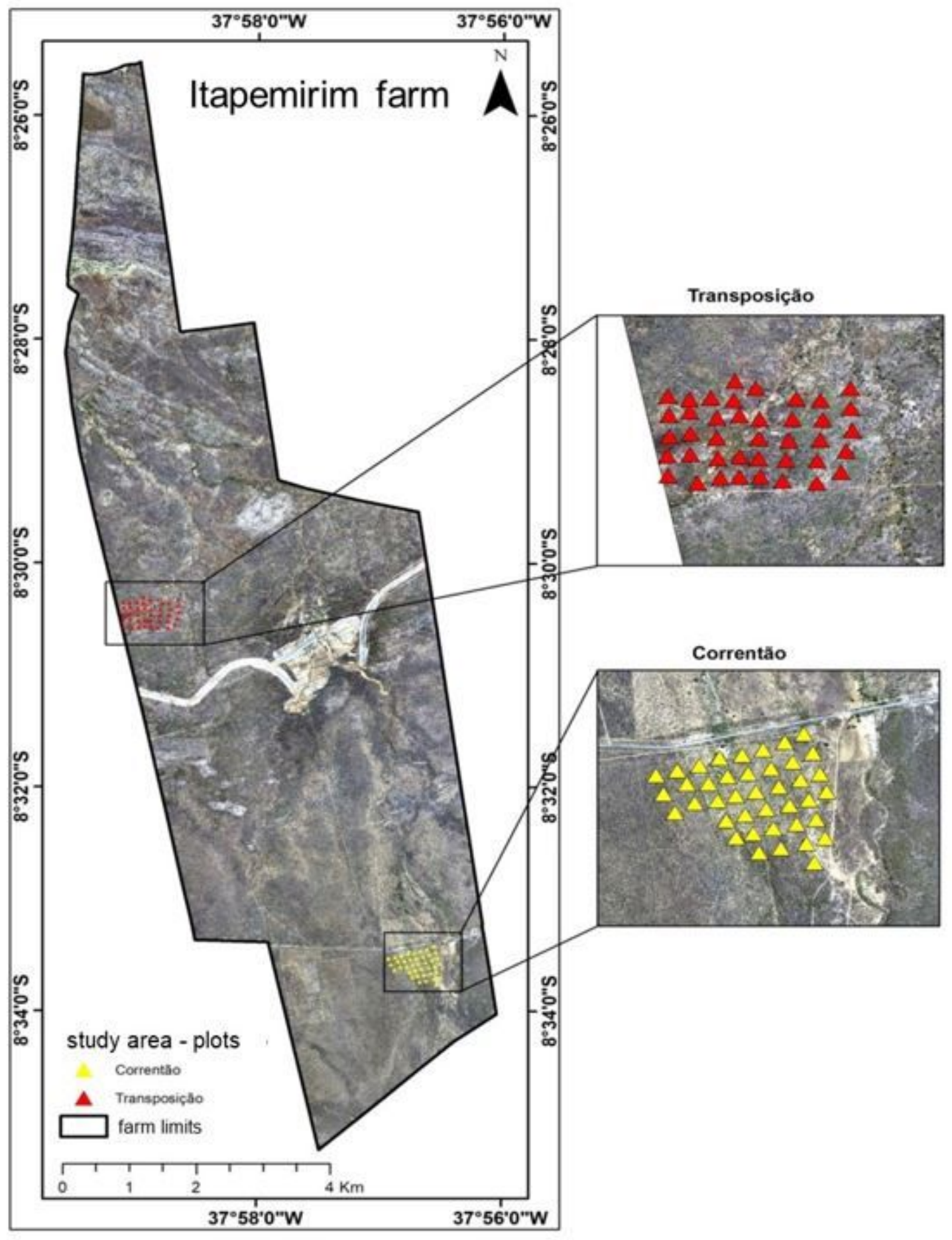

Figure 2

Sampling procedure used in the two inventoried areas in the Municipality of Floresta, Pernambuco 


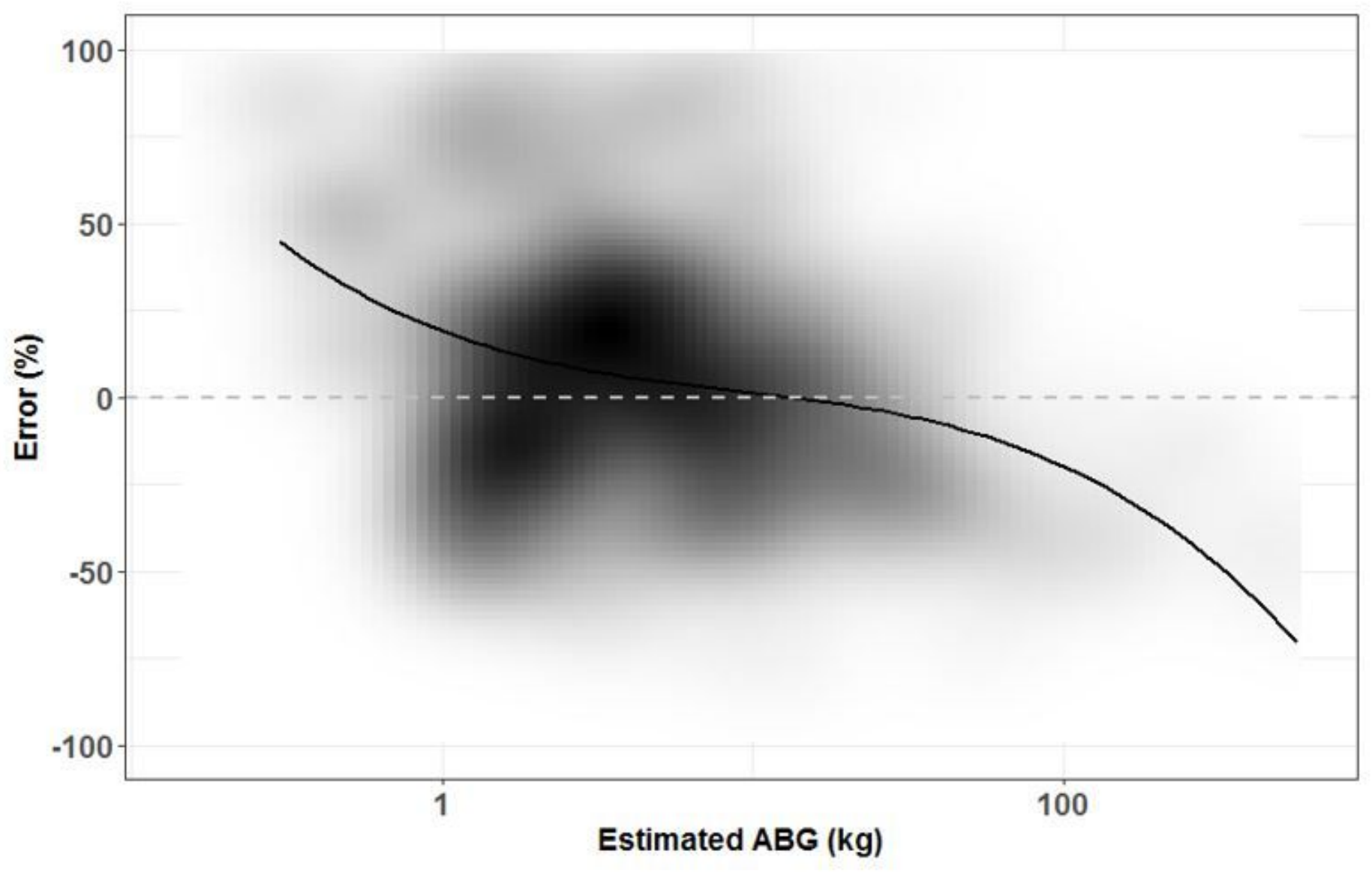

Figure 3

Dispersion of percentage residues for the Schumacher-Hall equation developed to predict biomass in dry tropical forest, northeastern Brazil. 

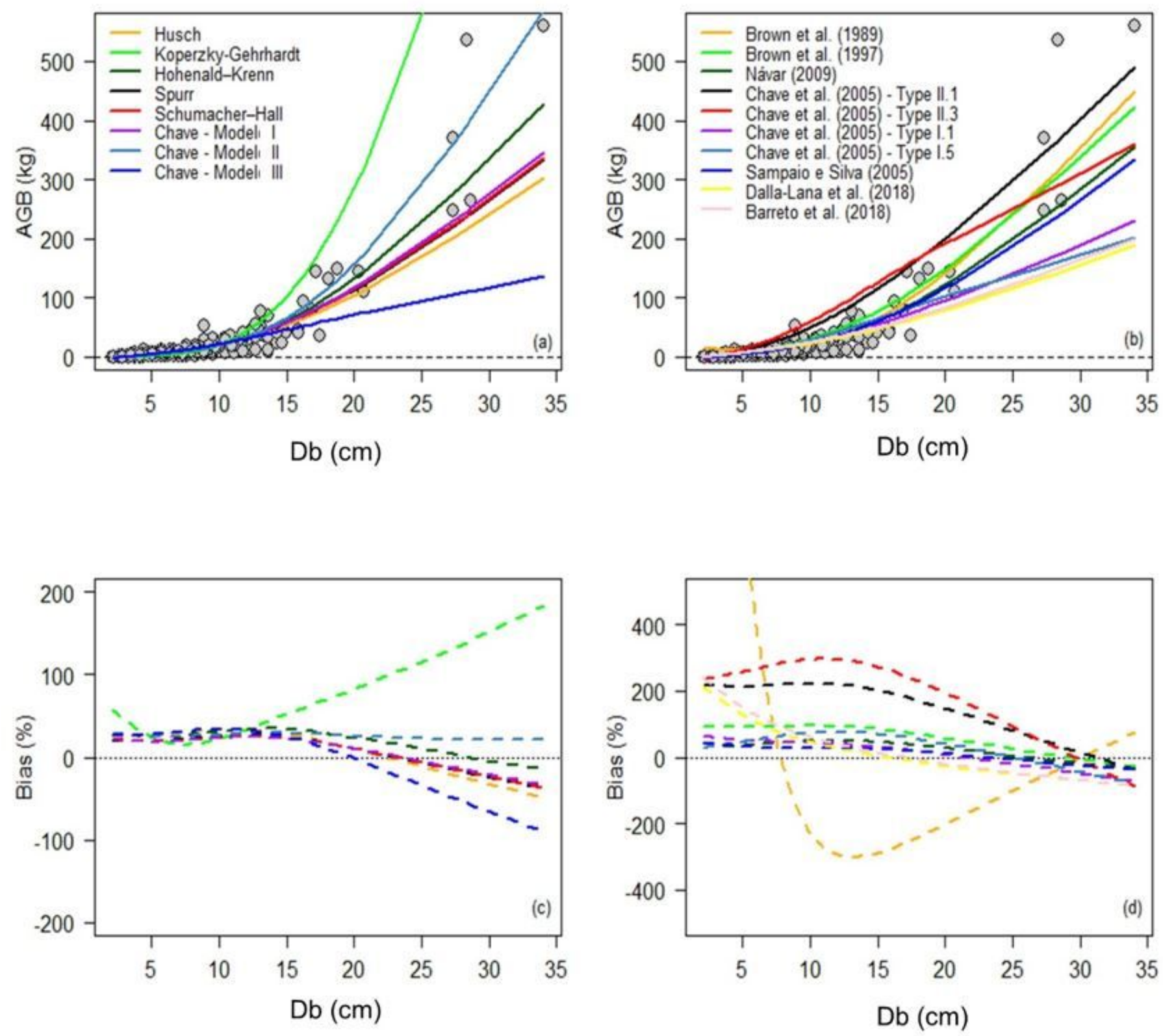

\section{Figure 4}

Biomass prediction from the equations developed for the site (a) and from other local and pan-tropical equations (b); and percentage difference (bias) of biomass predictions at tree level by diameter class for local equations (c) and other local and pan-tropical equations (d). 